\title{
Consumption Patterns of the Millenial Generational Cohort
}

\author{
Rebecca Abraham, Charles Harrington \\ Huizenga School of Business, Nova Southeastern University, Fort Lauderdale, FL, USA \\ Email: Abraham@nova.edu, charlieh@nova.edu
}

Received 25 November 2014; revised 10 December 2014; accepted 17 December 2014

Copyright (C) 2015 by authors and Scientific Research Publishing Inc.

This work is licensed under the Creative Commons Attribution International License (CC BY). http://creativecommons.org/licenses/by/4.0/

(c) (7) Open Access

\section{Abstract}

This study constructs a consumption profile for the Generation $Y$ age cohort using responses to the Consumer Expenditure Survey furnished by the Bureau of Labor Statistics from the financial crisis period. This generation was theorized to employ both economic reasons, i.e. preferences for inexpensive products, and the desire to comply with the values and normative beliefs of social referent groups. For the rent or buy a home decision, the variability of income, risk of foreclosure and loss of mobility governed the consumption choice. For the purchase a new car or a used car decision, economic considerations dominated with variability of income being the sole explanatory variable for the choice. Family size and the need to conform to group norms explained the choice of bringing food from home to the workplace. Socialization opportunities and group identification explained the decision to eat lunch away from the workplace. Family size and desire for group conformity explained vacation expenditure as they did for bringing food from home. For both furniture and large appliances and small appliances, the need to conform to group norms was significant suggesting that they may be the subject of social interactions. Given that investment in a private education is often considered a luxury, the proportion of the family budget allocated to this expense was significant along with the expected need for conformity with group values.

\section{Keywords}

Generation Y, Consumption Patterns, Millennial Generation, Utilitarian, Social Referent

\section{Introduction}

Generation Y or the Millenial Generation has been defined as those born from 1982-2002 [1]. This generationalcohort's consumption patterns may be based on economic uncertainty [2]. According to the permanent income hypothesis [3], consumption decisions are based on annuity income and wealth. Wealth declined from the 
financial shock of 2007 in which home equity values plummeted resulting in a subprime foreclosure rate of $43 \%$ on $6.8 \%$ of loans [4]. Less affordability depressed the demand for housing, and in turn, housing prices. Shrinking home equity left wage income the sole source of consumption income. The aggregate unemployment rate was found to predict the variability of income [5], while mere expectations of unemployment have been found to increase the variability of income [6], which in turn, decreased consumption [7].

Alternatively, Generation Y may be making consumption choices based on their regular contact with social referent groups through the Internet. The Internet has ben perceived as providing millenials with a new medium of social exchange and membership in online social communities [8]. Prior empirical research of this generational cohort has observed the importance of the immediate social circle in making consumption decisions with [9] and [10] emphasizing that consumption choices are based on the need to fit in and receive social approval. Gen Y adults in China have been observed to use their interactions with counterparts in other countries to build brand awareness which influences their purchases of luxury goods [11].

This study views consumption choices for Generation Y as arising from price consciousness due to variability of income from employment uncertainty that may disrupt the annuity wage stream and the need to conform to the expectations of the social referent group. Such an integrated approach is novel in that it combines social psychological theory and theories of economic utility. This is in accordance with the Sheth, Newman and Gross Model set forth both utilitarian and social values as driving consumption choices [12]. Yet, there is very sparse evidence of empirical verification of such integrated theory in the literature. We present evidence to meet this gap. Marketers may employ such profiles of consumer behavior in target promotions to this demographic segment. Consequently, the study seeks to fulfill both theoretical and practical objectives. With 8 separate product groups, we provide a more comprehensive study of consumption patterns than single-product studies. Our results may be summarized as economic considerations influencing the purchase of durables such as housing purchases and new car purchases. The increased variability of income with uncertain revenue streams prompted Gen Y to rent rather than buy and eschew new cars for their used counterparts. For less expensive durables such as furniture and both large and small appliances, social identification became the dominant criterion. Less statusconscious workers chose to forego socialization opportunities to further their careers, whereas their more upwardly mobile counterparts sought to interact with their aspirant group for lunch. Parents who supported private education for their children formed yet another group that was dependent upon social group identification. However, as the cost of private education is high, the percent of income spent upon private education restricted free choice.

\section{Theoretical Framework}

\subsection{The Economic Justification for Reduced Consumption}

The cornerstone of the permanent-income hypothesis (PIH) was that consumption decisions were driven by the expectation of a permanent stream of annuity wage income along with wealth. Until 2007, continued employment meant the assurance of permanent wage income. Wealth originated from home equity buoyed by rising home values. The Case-Shiller Housing Index reached a peak of 189.93 in the second quarter of 2006 with base value of 100 in 2000 [13]. A bubble was created from increased demand for housing by 25\% of the public who did not qualify for traditional mortgages due to derogatory credit or limited income [14]. These subprime borrowers qualified for adjustable-rate mortgages with low introductory interest rates set to rise in the future [15].

As interest rates on subprime mortgages rose in 2007, many borrowers could not meet the higher payments resulting in a subprime foreclosure rate of $43 \%$ on $6.8 \%$ of loans [4]. Higher subsequent rates on adjustable-rate mortgages resulted in an unforeseen utility loss. Less affordability depressed the demand for housing, reducing the Case-Shiller Index to 129.1 in the first quarter of 2011 [13]. With the shrinking of home equity, wage income remained the sole source of consumption income. Intuitively, consumption would be reduced by disruptions to the continuity of the permanent income stream. Empirically, the introduction of variability of income as an explanatory variable has ben found to render income growth insignificant [16]. What causes such variability of income? One reason may be unemployment. The aggregate unemployment rate and its change predicted the variance of income and income growth [5]. Yet, expectations of unemployment may be as equally effective as actual unemployment in restricting consumption growth as significant decreases of aggregate consumption for reductions in permanent and transitory income have been found to be induced by expectations of unemployment [6]. We may envision uneven consumption growth, with increasing demand for certain products, and declining 
or stable demand for others.

\subsection{The Influence of Social Referent Groups in Consumption Decisions}

Weber's theory of social class motivates consumption in that membership in a social class confers linkage among members through a common lifestyle and accompanying social restrictions. Social status determines consumption particularly of conspicuous items such as houses and cars as such purchases symbolize membership in a high-status social referent group [17]. There are several studies that document the importance of social referent groups in making consumption decisions, though only a single one typifies the choices made by Generation Y. In this study, young adults used social media to obtain prices for wine, which was then consumed with partners and friends [18]. This finding is supported by the practice of buying rounds in British pubs by each member of the group to enhance the drinking experience. The desire to maintain membership in high-status groups was evident in an experiment in which for some goods up to $80 \%$ of the respondents opted for choices in which they were at a relatively higher income than their peers [19]. Positionality was more important for visible items consumed such as houses and cars than nonvisible items such as vacation and insurance [20]. Donors to charity desired membership in high-donation categories (when donors were demarcated by size of contribution), and such levels of contribution were fully disclosed and recognized [21].

\subsection{The Rent or Buy Decision}

Based on [22], we propose the following decision problem using the rent or buy decision as an example. All the possible outcomes are represented by $W$, in a decision space $D$. One outcome is $w$, rent or buy a dwelling. The consumer must decide between the two choices, making a decision $d$, using an estimate of $r$, the reward of either the rent or buy outcome. Economic rewards of renting include no risk of foreclosure, mobility and lack of maintenance costs. We maintain that with high variability of income in an environment of uncertain job security, the lack of risk of foreclosure from renting merits the highest probability of reward. Economic rewards of buying include stability, status and pride of ownership. Status variables include housing expenditure by members of the social referent group with group members desiring to spend at a level that is average for the group and the related concept of owning a home that is attractive and well-kept so as not to diminish one's status within the referent group. The sum total of these $r$ rewards for each choice is $\sigma w(d)$.

Therefore, DeGroot (1970) specifies the probability of each benefit, say $B$, to be

$$
P_{d}(B)=P_{d}[\sigma(W, d) € B]=P[w: \sigma(w, d) € B]
$$

Consumers will make the decision to rent or buy based on the choice that confers the greater utility of satisfaction given the total probability of realization of all benefits of a particular choice, $P_{d}$, where, $P_{d}=P(A)+P(B)+P(C)+\cdots$ with

$P(A), P(B), P(C)=$ the probability of each benefit.

$$
\begin{aligned}
& E\left(U \mid P_{d}\right)=\int R U(r) \mathrm{d} P_{c}(r) \\
& E\left(U \mid P_{d}\right)=\int R U(r) \mathrm{d} P_{c}(r)
\end{aligned}
$$

For renting,

$$
E\left(U \mid P_{d}\right)=\int R\left[p_{a} V I+p_{c} M O+p_{d} L S\right] \mathrm{d} P_{c}(r)
$$

For buying,

$$
E\left(U \mid P_{d}\right)=\int R\left[p_{a} H E+p_{b} H A+p_{c} L S+p_{d} V I+p_{e} P F\right] \mathrm{d} P_{c}(r)
$$

where,

$V I=$ Variability of income.

$P F=$ Prevention of foreclosure.

$M O=$ Mobility.

$H E=$ Housing expenditure.

$H A=$ House appearance. 
$L S=$ Labor supply or number of earners added to both the utility of renting and the utility of owning.

For renting, the risk of foreclosure is always $=0$. With increasing variability of income, a long-term fixed expense such as a mortgage becomes increasingly unaffordable, thereby increasing the risk of foreclosure. Therefore, $p_{e}$, the probability of reward from preventing foreclosure may become so excessively high for homeowners that prospective home buyers may opt for renting. We pose the following exploratory research question.

Research Question 1: What are the predictors of the decision to rent or purchase a dwelling as the primary source of shelter for the Generation Y age cohort?

\subsection{Purchase a New Car or Purchase a Used Car}

As a durable, the purchase of a new car involves a large up-front payment or a large stream of annuity payments as a percentage of wages. When income becomes variable, through loss of work hours or employment, the ability to meet the stream of annuity payments is curtailed, or the new car becomes much less affordable. The payment of smaller up-front payment or a smaller monthly payment assures that the posterior probability of reward, $\xi(w \mid x)$, for a new car may decline. A steady stream of negative economic news about layoffs, business closures and other adverse economic forecasts are contained in variable $x$, so that the original (prior) reward from purchasing a new car gets revised to a lower posterior probability of reward, rendering the used car the more attractive option.

The original posterior (final) probability of reward for a new car is represented as

$$
\xi(w \mid x)=f(x \mid w) \xi(w) / \int U f\left(x \mid w^{\prime}\right) \xi\left(w^{\prime}\right) \mathrm{d} v(w)
$$

where,

$f(x \mid w)=$ Utilitarian values such as the need for transportation.

$\xi(w)=$ Prior probability density function of $w$, or reward of status from owning a new car.

$f\left(x \mid w^{\prime}\right)=$ Optimal level of utilitarian norms with maximum affordability and satisfaction of demographic needs.

$\xi^{\prime}(w)=$ Prior probability density function that minimizes risk.

Concomitant with this posterior probability, would be a decision risk $\rho(\delta)$, which with certainty of a future income stream renders the new car purchase to be achieved at minimum risk denoted by $\rho(\delta)^{*}$. This is the Bayes decision for at the beginning of the period when the new car purchase is still financially viable.

In the next phase, the posterior probability density functionin (5), $\xi(w \mid x)$, becomes the new prior probability $\xi^{\prime}(w)$,

$$
\xi^{\prime \prime}(w \mid x)=f(x \mid w) \xi^{\prime}(w) / \int U f\left(x \mid w^{\prime \prime}\right) \xi\left(w^{\prime \prime}\right) \mathrm{d} v(w)
$$

where

$\xi^{\prime}(w)=$ Diminished probability of reward from new car ownership due to adverse economic news.

$f\left(x \mid w^{\prime \prime}\right)=$ Optimal level of satisfaction of the need for transportation which is lower than the optimal level in (5) due to adverse economic news, $x$.

$\xi\left(w^{\prime \prime}\right)=$ Revised probability of reward that minimizes risk.

With the revision of $x$, the optimal decision risk $\rho(\delta)^{*}$ in (5)is no longer optimal, i.e. it does not minimize additional risks implied by the new $x$.

Such reduction of consumption may only be realized by purchasing the used car.

We may pose this exploratory research question.

Research Question 2: What are the predictors of the decision to purchase a new car or purchase a used car by the Generation Y age cohort?

\subsection{Determinants of Bringing Food from Home to the Workplace}

Anthropologists and social psychologists have recognized the importance of food as a form of developing social 
class relationships through the sharing of food [23] [24]. In successive studies, Generation Y was observed to be attracted to TV shows that depicted the consumption of wine as a social facilitator [25] [26]. Therefore consumption may be predicated on the basis of socialization opportunities with the need to conform to one's own social referent group and the other group, i.e. the group that eats lunch away from the workplace. The consumer's own social referent group provides an opportunity for interaction as group members consume food together in a common break room or cafeteria. As this is the group that meets regularly, group members are likely to seek the greatest conformity with this social referent community. As restaurant food is more high priced than food brought from home, the Food Away Group may be an aspirant group in that the Food at Home cohort aspires to be able to afford to eat away from the workplace and in doing so, interact with members of a social referent group that is more affluent than their own social class. The underlying concept of aspiring to a higher social referent group is entrenched in the literature on group dynamics. Achievement vanity may exist in the purchase of luxuries to elevate social status by Chinese consumers [27] [28]. It has been empirically found that when wine was purchased by Generation Y for a special purchase or gift it had to reflect the giver who purchased more expensive premium wines in an attempt to trade up [18]. Intuitively, family size may also act as a determinant of Food at Home expenditure, with workers with larger families restricting their expenditure on food to accommodate larger food budgets.

$$
E(U)=f(S O, D E F H, D E F A, L t, F S)
$$

$S O=$ Socialization Opportunities.

$D E F H=$ Deviation of Consumer's Food Expenditure on Food brought from Home from the mean of the reference group,

$D E F A=$ Deviation of Consumer's Food Expenditure from the mean of the reference group that eats away from Home.

$L S=$ Labor Supply.

$F S=$ Family Size.

We may pose this exploratory research question.

Research Question 3: What are the predictors of expenditure on food brought from home to the workplace by the Generation Y age cohort?

\subsection{Determinants of Eating Lunch Away from the Workplace}

An individual who eats away from the workplace is usually at a higher managerial or professional level who uses these relationships to further their careers by creating new business opportunities. Therefore, we would expect that socialization opportunities, $S O$, and the desire to conform to the norms of this group, DFA, would be of value to such individuals. However, such variables, albeit important, are not the only determinants of eating away from the workplace. We may envision a psychological consumption function composed of variables that cater both to individual needs and those that are based on social referent group identification.

$$
U_{c}=(V I+F S+F H+L S)+(D F A+D F H+S O)
$$

where

$U_{c}=$ Utility of consumption for a rising professional.

$I C=$ Variables influencing individual consumption.

$S R G=$ Variables influencing socially appropriate consumption.

$V I=$ Variability of income.

$D F A H=$ Deviation from expenditure of the Food at Home group.

$F S=$ Family Size.

$F H=$ Food at Home.

$L S=$ Labor supply.

$D F A=$ Deviation from expenditure of the Food Away from Home group.

$S O=$ Socialization opportunities.

All of the sources of individual consumption depend on wages, including variability of income, restrictions due to large family size and contributions from multiple earners. The source of consumption influenced by social groups includes both deviation from the Food Away from Home and Food at Home groups. If we assume 
that upwardly mobile individuals are more concerned with professional development than being parsimonious, the change in individual consumption variables remains constant over time.

$$
\mathrm{d} V I / \mathrm{d} t=k_{1}, \mathrm{~d} F S / \mathrm{d} t=k_{2}, \mathrm{~d} F S / \mathrm{d} t=k_{3}, \mathrm{~d} F H / \mathrm{d} t=k_{4}, \mathrm{~d} L S / \mathrm{d} t=k_{5}
$$

While the career enhancement potential of eating significant mentors and supervisors is obvious, the importance of considering deviations from the Food at Home group is less clear. Possibly, this group is observed to assure that the professional's status does not diminish, i.e. with an uncertain economic environment, the rate of change in investment in Food Away may decrease though not to the level of the Food at Home group. The Food at Home group sets a lower bound below which the expenditure of the Food Away from Home group will not fall.

Accordingly, if we differentiate the utility function specified in (8) with respect to time,

$$
\mathrm{d} U_{c} / \mathrm{d} t=\mathrm{d} I C / \mathrm{d} t+\mathrm{d} D F A / \mathrm{d} t+\mathrm{d} D F H / \mathrm{d} t+\mathrm{d} S O / \mathrm{d} t
$$

Given the relative importance of the social referent group variables, we omit $\mathrm{d} I C / \mathrm{d} t$,

$$
\mathrm{d} U_{c} / d t=\mathrm{d} D F A / \mathrm{d} t-\mathrm{d} D F H / \mathrm{d} t+\mathrm{d} S O / \mathrm{d} t
$$

At the lower bound,

$$
\mathrm{d}^{2} U_{c} / \mathrm{d} t^{2}=\mathrm{d}^{2} D F A / \mathrm{d} t^{2}-\mathrm{d}^{2} D F H / \mathrm{d} t^{2}+\mathrm{d}^{2} S O / \mathrm{d} t^{2}
$$

$\mathrm{d}^{2} D F H / \mathrm{d} t^{2}=$ Mean expenditure by Food at Home group on food brought to work.

The continual decrease in utility of the deviation from expenditure of the Food at Home group merits a negative sign.

We may pose this exploratory research question.

Research Question 4: What are the predictors of expenditure on food eaten away from the workplace by the Generation $\mathrm{Y}$ age cohort?

\subsection{Determinants of Vacation Expenditure}

It has observed that Generation Y members often express a preference for appealing environments offering experiential activities [29]. These activities have been termed fantasy fulfillment purchasing with high levels of sensory stimulation particularly in distant locations suggested by social referent communities met on the Internet [30]. This suggests that social referent groups may drive vacation choices and spending. The primary economic variable is family size. Large family size may be beneficial in that it permits richer shared experiences, so that the sign on the family size variable may be reversed. Economic variables may be of secondary importance as the expense of travel does not seem to have concerned most members of this cohort. Travel spending for Generation Y approached \$140 million with annual worldwide expenditure at \$200 billion [31]. There is consensus in the literature that Generation Y has a significant amount of discretionary spending available [32]. Therefore, variability of income only adversely affects consumers who do not have this guaranteed stream of vacation funding. Likewise, labor supply with more earners in the family only benefits those who are financially constrained from making certain vacation choices.

For most consumers, the utility of vacation expenditure given funding is dependent on family size and deviation from the social referent group with constants for variability of income and labor supply.

$$
\begin{aligned}
& E\left(U_{v} \mid F\right)=U(S R G)+k_{1}(V I)+k_{2}(L S) \\
& E\left(U_{v} \mid F\right)=U(F S+D E S G)+k_{1}(V I)+k_{2}(L S)
\end{aligned}
$$

where

$U_{v}=$ Utility of vacation expenditure.

$F=$ Funding for vacations.

FS = Family size.

$D E S G$ = Deviation from social referent group.

$V I=$ Variability of income.

$L S=$ Labor supply.

$S R G=$ Social referent group. 
For the smaller percentage of consumers who are financially constrained, the utility of vacation expenditure depends upon both social referent group variables and economic (variability of income and labor supply) variables.

$$
\begin{gathered}
E\left(U_{v} \mid F\right)=S R G+V I+L S \\
E\left(U_{v} \mid F\right)=F S+D E S G+V I+L S
\end{gathered}
$$

As variability of income increases, an offsetting trend may be an increase in labor supply with more earners so that the level of vacation spending may remain almost unchanged. Empirically both, variability of income and labor supply must be included.

Differentiating with respect to VI,

$$
\mathrm{d}\left[E\left(U_{v} \mid F\right)\right] / \mathrm{d} V I=\mathrm{d}(F S) / \mathrm{d} V I+\mathrm{d}(D E S G) / \mathrm{d} V I+1+\mathrm{d}(L S) / \mathrm{d} V I
$$

Research Question 5: What are the predictors of vacation expenditure by the Generation Y age cohort?

\subsection{Determinants of Expenditure on Furniture and Large Appliances}

For millenials who are largely renters, the expenditure on furniture and appliances may not accompany home purchases. They may be more discretionary status symbols. The literature has found evidence that when household furnishings are observed, social class identifications occur [33]-[36] in the form of decoding messages about owners. Further, there is a need to minimize the risk of being considered to be of diminished social status. Style of residence has been found to create inferences about the personality and lifestyle of the resident with more expensive furnishings denoting membership in a social class that may be higher than that suggested by income and demographics [37] [38]. Therefore, deviation from the social referent group and diminished status may be determinants of expenditure on furniture and large appliances. Labor supply and family size may have opposite effects on discretionary spending with more earners increasing expenditure on furniture and appliances and larger families restricting expenditure on furniture and appliances.

$$
\begin{gathered}
E\left(U_{f}\right)=U(S R G)+L S+F S \\
E\left(U_{f}\right)=U(D E+D S)+L S+F S
\end{gathered}
$$

where

$U_{f}=$ Utility of expenditure on furniture and large appliances.

$F S=$ Family size.

$D E=$ Deviation from social referent group.

$D S=$ Diminished status.

$L S=$ Labor supply.

$S R G=$ Social referent group.

As furniture and large appliances are purely discretionary purchases, yet with sufficient visibility to confer status upon consumers, as the number of earners increases, consumers are likely to purchase more of these items to increase their prestige with social group members. Labor Supply imposes an lower bound on furniture and large appliance expenditure. Conversely, as Family Size reaches a maximum, restrictions on discretionary spending ensue, thereby imposing an upper bound on furniture and large appliance spending. These relationships are modeled as follows.

As family size increases, more funds are spent on furniture and appliances (mainly due to necessity) so that the utility of meeting group norms, and maintaining status in the group increases as labor supply increases to meet the additional expenditure,

$$
\mathrm{d}\left[E\left(U_{f}\right)\right] / \mathrm{d} F S=\mathrm{d} U(D E) / \mathrm{d} F S+\mathrm{d} U(D S) / \mathrm{d} F S+\mathrm{d}(L S) / \mathrm{d} F S
$$

At the upper bound,

$$
\begin{gathered}
F S \rightarrow \infty, \frac{\mathrm{d}^{2} F S}{\mathrm{~d} F S^{2}}=0 \\
\mathrm{~d}^{2}\left[E\left(U_{f}\right)\right] / \mathrm{d} F S^{2}=\mathrm{d}^{2} U(D E) / \mathrm{d} F S^{2}+\mathrm{d}^{2} U(D S) / \mathrm{d} F S^{2}+\mathrm{d}^{2}(L S) / \mathrm{d} F S^{2}
\end{gathered}
$$


As labor supply decreases, even with no increase in family size, fewer funds are spent on furniture and appliances. However, spending is not curtailed completely as status within the group must be maintained. A minimum level of expenditure on these items assures that there is a minimum positive utility of satisfaction with maintenance of position within the group.

At the lower bound, $L S \rightarrow 1$,

$$
\begin{gathered}
E\left(U_{f}\right)=U(D E+D S)+L S+F S \\
\mathrm{~d}^{2}\left[E\left(U_{f}\right)\right] / \mathrm{d} L S^{2}>0
\end{gathered}
$$

Research Question 6: What are the predictors of vacation expenditure by the Generation Y age cohort?

\subsection{Determinants of Expenditure on Small Appliances}

Small appliances such as coffee makers, blenders and food processors serve a utilitarian function, i.e. they are used to enhance convenience. They are not status symbols. Consumers will simply wish to maintain their expenditure on these items at the median level of the social referent group. An increase in labor supply may increase consumption of these items if they reduce the time for food preparation as more earners will escalate the need for quick meals. An increase in family size may increase consumption though such an increase may only occur for very large families who find that the existing appliances do not have the capacity to accommodate the needs of a large family. We may pose the research question:

Research Question 7: What are the predictors of expenditure on small appliances by the Generation Y age cohort?

\subsection{Determinants of Expenditure on Private K-12 School Tuition}

The National Center for Policy Analysis framed the core argument in favor of private schools as the failure of the public system to recognize that students have specific areas of subject interest and ability and that curricula should be designed to meet those individualized needs. Grouping by age instead of subject interest reduces student engagement and academic achievement [39]. Parents who subscribe to these beliefs tend to have similar household incomes [40] and educational levels [41]. Such individuals belong to a particular social reference group that is so unified in its beliefs that each member seeks to adhere to group norms. The only constraint to educating children in private schools is family size. With an increase in the number of children attending private schools, tuition expenditure escalates, so that the percentage of household spending on private education reaches a maximum. If this maximum is achieved before the needs of all of the children are met through the original choice of school, parents are likely to seek less expensive private school alternatives, thus maintaining their position in the social referent group while staying achieving their budget constraint (25).

$$
E\left(U_{p}\right)=f(S R G, F S, H S)
$$

where

$E\left(U_{p}\right)=$ Expected utility of private education.

$S R G=$ Social referent group.

$F S=$ Family Size.

$H S=$ Percentage of Household Expenditure on Private Education.

Research Question 8: What are the predictors of Generation Y's consumption of private K-12 education?

\section{Data and Methodology}

Consumption data were collected from the Bureau of Labor Statistics's Consumer Expenditure Survey's Interview files which collected household consumption data from 2006-2009. This period was chosen as it covered the financial crisis with expected declines in consumption. The period of time was selected as it represented a time of high unemployment, with expected increases in variability of income-viewed as a particularly important variable in housing and automobile purchase decisions. Subsequently, unemployment expectations have declined, so that more contemporary data may not reflect the importance of variability of income in determining 
consumption. Study [7] observed the importance of variability of income in the aftermath of the Great Depression. Consequently, this study included variability of income in a similar contemporary period of high unemployment and high unemployment expectations. Two types of Interview files were created. The first form were

Income files with annual wages, number of earners (labor supply), education, family size and age. Expenditure data was obtained from expenditure files which included housing expenditure, mortgage, home insurance, home taxes, home repair, rent, debt, new car price, used car price, car registration, car insurance, car maintenance, car repair, lunch at home, lunch away from home, vacation expense, new furniture expense, new appliance expense, small appliance expense and private school tuition expense. All variables were scaled by total household expenditure. Deviations were measured as difference from the mean. Dichotomous variables for status (0 for renters, 1 for home buyers), mobility ( 1 for renters, 0 for home buyers) and risk of foreclosure ( 1 for deviations of housing expenditure above the mean, 0 for deviations of housing expenditure below the mean were created. A Generation Y sample of 2331 consumers was extracted with ages $<30$ and incomes $<\$ 30,000$. Eight OLS regressions measuring the relationships outlined in Sections 2.3 - 2.9 were conducted. To maintain brevity, regression equations are not repeated in this section, but are more thoroughly discussed in Results.

\section{Results}

As reported in Table 1, Exploratory Question 1 was affirmed in that the more variable the income and the greater the risk of foreclosure, the more likely the consumer will elect to rent (coefficient $=1.7 \times 10^{-6}, \mathrm{p}<0.001$ for variability of income; coefficient $=1.36 \times 10^{-1}, \mathrm{p}<0.001$ for risk of foreclosure) followed by loss of mobility which diminishes for renters (coefficient $=-3.33 \times 10^{-4}, \mathrm{p}<0.01$ ). Exploratory Question 2 was partly affirmed with variability of income encouraging consumers to purchase used cars (coefficient $=0.19, \mathrm{p}<0.01$ ). Other economic variables including the price of a new car, price of a used car, cost of car maintenance and labor supply were insignificant. Exploratory Question 3 with the desire to minimize the deviation from one's social referent group $($ coefficient $=17.28, \mathrm{p}<0.001$ ), increased socialization opportunities $($ coefficient $=23.22, \mathrm{p}<$ 0.01 ) and minimize deviation from the Eat Away group (coefficient $=4.56, \mathrm{p}<0.01$ ) increasing the likelihood of food brought from home. The only economic restriction is family size (coefficient $=1.97, \mathrm{p}<0.05$ ) which when increasing imposes budgetary restrictions on eating away thereby increasing the probability that food will be brought from home. Research Question 4 was partly affirmed in that consumers used socialization opportunities (coefficient $=0.95, \mathrm{p}<0.05$ ) which were the norm for their own social referent group (coefficient $=8.04, \mathrm{p}<$ 0.001 ) to further their careers by eating food away from the workplace. Research Question 5 was also partly affirmed with minimization of deviation from social referent group (coefficient $=0.04, \mathrm{p}<0.001$ ) and reduction in family size (coefficient $=-0.01, p<0.01$ ) being significant predictors of vacation expenditure unlike variability of income and labor supply. Reduction in family size may provide enhanced funding for vacations thereby improving the quality of the travel experience. Research Questions 6 and 7 were affirmed with minimization of the deviation from social referent group's expenditure influencing the expenditure on both furniture and large appliances (coefficient $=0.04, \mathrm{p}<0.001$ ) and small appliances (coefficient $=0.01, \mathrm{p}<0.001$ ). Research Question 8 was affirmed with limiting the deviation from referent group's consumption increasing expenditure on private K-12 education (coefficient $=289.12, \mathrm{p}<0.001$ ) and increasing percent of household expenditure on tuition (coefficient $=-276.42, p<0.05)$ reducing expenditure on private school tuition. $R^{2}$ values of $0.23-0.59$ suggest that there may be additional noneconomic or nonsocial psychological variables which must be investigated in future empirical studies (Table 2).

\section{Conclusion}

Economic considerations predisposed choice for large durables such as housing purchases and new car purchases. Concerns about the increased variability of income prompted Gen Y to rent rather than buy and eschew new cars for their used counterparts. Convenience considerations, such as mobility were secondary to economic concerns about the risk of foreclosure. On the other hand, for less expensive durables such as furniture and both large and small appliances social identification became the dominant criterion. The venue of lunch consumption led to the emergence of two distinct social reference groups. For less upwardly mobile workers, the interaction with similar peers sufficed to determine food expenditure, whereas their more upwardly mobile counterparts sought to eat with their aspirant group at locations away from the workplace. Socialization motives were thus differentiated based upon the location of food consumption. Parents who supported private education for their 
Table 1. Descriptive statistics.

\begin{tabular}{|c|c|c|}
\hline Variable & Mean & Standard Deviation \\
\hline Wages & $\$ 21942.10$ & $\$ 19129.18$ \\
\hline Homeowner Frequency & 1311 & $\mathrm{Na}$ \\
\hline Renter Frequency & 1020 & $\mathrm{Na}$ \\
\hline Gender & 1999 Men, 342 Women & $\mathrm{Na}$ \\
\hline Race & 1134 Caucasian, 1197 African-American & $\mathrm{Na}$ \\
\hline Education & 1140 College-Educated, 1191 High-School Graduates & $\mathrm{Na}$ \\
\hline Age & 23.945 Years & 4.38 \\
\hline Family Size & 3 Individuals & $\mathrm{Na}$ \\
\hline Variability of Income & $\$ 3208.835$ & $\$ 19149.36$ \\
\hline Mortgage & $\$ 1892.128$ & $\$ 1541.66$ \\
\hline Home Insurance & $\$ 282.873$ & $\$ 350.34$ \\
\hline Home Taxes & $\$ 468.64$ & $\$ 484.12$ \\
\hline Rent & 14665.34 per Year & 430825.03 per Year \\
\hline Debt & $\$ 8736.59$ & $\$ 16051.51$ \\
\hline Cost of a New Car & $\$ 13103.73$ & $\$ 8076.04$ \\
\hline Cost of a Used Car & $\$ 4594.68$ & $\$ 7003.88$ \\
\hline Car Payment & \$553.97 per Quarter & $\$ 424.22$ \\
\hline Car Registration & \$111.46 per Year & $\$ 161.62$ \\
\hline Car Insurance & $\$ 341.75$ & $\$ 263.38$ \\
\hline Car Maintenance & $\$ 68.30$ per Quarter & $\$ 157.02$ \\
\hline Car Repair & $\$ 2458.18$ & $\$ 56355.96$ \\
\hline Lunch at Home & 1723 Individuals & $\mathrm{Na}$ \\
\hline Lunch Away from Home & 1473 Individuals & $\mathrm{Na}$ \\
\hline Vacation Expense & $\$ 350.49$ per Person & $\$ 614.255$ \\
\hline New Furniture & $\$ 510.52$ & $\$ 923.70$ \\
\hline New Appliances & $\$ 1023.33$ & $\$ 1673.18$ \\
\hline Small Appliances & $\$ 59.83$ & $\$ 69.35$ \\
\hline Tuition & $\$ 571.28$ & $\$ 782.80$ \\
\hline$N=2331$ & & \\
\hline
\end{tabular}


Table 2. Results of OLS regressions.

\begin{tabular}{|c|c|c|}
\hline Rent or Buy-Regression 1 & Coefficient & Significance \\
\hline Constant & $1.30^{* * *}$ & 0.0000 \\
\hline Variability of Income & $1.7 \times 10^{-6 * * *}$ & 0.0005 \\
\hline Risk of Foreclosure & $4.36 \times 10^{-1 * * *}$ & 0.0000 \\
\hline Diminished Status & $-7.30 \times 10^{-5}$ & 0.5925 \\
\hline Loss of Mobility & $-3.33 \times 10^{-4^{* *}}$ & 0.0025 \\
\hline Loss from Limited Labor Supply & $-0.07 \times 10^{-6}$ & 0.0604 \\
\hline Deviation from Group & $5.9 \times 10^{-5}$ & 0.4387 \\
\hline \multicolumn{3}{|l|}{$\mathrm{R}^{2}=0.32, \mathrm{~N}=1476$} \\
\hline \multicolumn{3}{|l|}{ New Car or Used Car-Regression 2} \\
\hline Constant & 88.67 & 0.8610 \\
\hline Variability of Income & $-0.19^{* *}$ & 0.0061 \\
\hline Price of a New Car & 21.85 & 0.6156 \\
\hline Price of a Used Car & 44.66 & 0.7321 \\
\hline Cost of Car Maintenance & -15.88 & 0.5995 \\
\hline Loss from Limited Labor Supply & 41.94 & 0.3898 \\
\hline \multicolumn{3}{|l|}{$\mathrm{R}^{2}=0.3978, \mathrm{~N}=74$} \\
\hline \multicolumn{3}{|l|}{ Bring Food from Home-Regression 3} \\
\hline Constant & 21.07 & 0.0765 \\
\hline Family Size & $1.97^{*}$ & 0.00147 \\
\hline Food Away from Home & 0.03 & 0.5912 \\
\hline Variability of Income & $4.25 \times 10^{-5}$ & 0.6667 \\
\hline Loss from Limited Labor Supply & -3.43 & 0.5813 \\
\hline Socialization Opportunities & $23.22^{* * *}$ & 0.0001 \\
\hline Deviation from Own Group & $17.28^{* * *}$ & 0.0000 \\
\hline Deviation from Aspirant Group & $4.56^{* *}$ & 0.0020 \\
\hline \multicolumn{3}{|l|}{$\mathrm{R}^{2}=0.2371, \mathrm{~N}=725$} \\
\hline \multicolumn{3}{|l|}{ Eats Away from Home-Regression 4} \\
\hline Constant & $28.76^{* * *}$ & 0.0005 \\
\hline Family Size & 0.89 & 0.3823 \\
\hline Food from Home & 0.01 & 0.5912 \\
\hline Variability of Income & $-5.92 \times 10^{-5}$ & 0.3855 \\
\hline Loss from Limited Labor Supply & 0.69 & 0.8728 \\
\hline Socialization Opportunities & $-7.95^{*}$ & 0.0471 \\
\hline Deviation from Food at Home Group & -2.03 & 0.0778 \\
\hline Deviation from Own Group & $8.04^{* * *}$ & 0.0000 \\
\hline
\end{tabular}




\section{Continued}

$$
\mathrm{R}^{2}=0.08, \mathrm{~N}=717
$$

Vacation Expenditure-Regression 5

\begin{tabular}{lcc} 
Constant & $0.25^{* * *}$ & 0.0000 \\
Family Size & $-0.01^{*}$ & 0.0068 \\
riability of Income & 0.04 & 0.0000 \\
to Limited Labor Supply & 0.02 & 0.6853 \\
\hline
\end{tabular}

Loss due to Limited Labor Supply

$$
\mathrm{R}^{2}=0.46, \mathrm{~N}=170
$$

Furniture, Appliances-Regression 6

\section{Constant}

Deviation from Group

Diminished Status

Loss from Limited Labor Supply

Family Size

$\mathrm{R}^{2}=0.51, \mathrm{~N}=213$

Small Appliances-Regression 7

Constant

Deviation from Group

Loss Due to Limited Labor Supply

$$
\text { Family Size }
$$

$$
\mathrm{R}^{2}=0.59, \mathrm{~N}=117
$$

Private School Tuition-Regression 8

$$
\text { Constant }
$$

Percent of Household Expenditure

$$
\begin{gathered}
\text { Deviation from Group } \\
\text { Family Size } \\
\mathrm{R}^{2}=0.33, \mathrm{~N}=38
\end{gathered}
$$

$\begin{array}{ll}0.20^{* * *} & 0.0000 \\ 0.04^{* * *} & 0.0000 \\ 0.11 & 0.1446 \\ 0.04 & 0.2529 \\ -0.01 & 0.6818\end{array}$

$\begin{array}{ll}0.01^{* * *} & 0.0000 \\ 0.01^{* * *} & 0.0000 \\ -0.01 & 0.2901 \\ 0.01 & 0.4583\end{array}$

$2139.21^{* * *} \quad 0.0000$

$-276.42^{*} \quad 0.0152$

$289.12^{* * * *} \quad 0.0002$

$\begin{array}{ll}-75.12 & 0.0830\end{array}$

offspring formed yet another group that was dependent upon social group identification. However, as the cost of private education is considerably higher than food expenditure, household spending upon private education acted as a constraint.

\section{References}

[1] Pendergast, D. (2010) Getting to Know the Y Generation. In: Benckendorff, P., Moscardo, G., Pendergast, D., Eds., Tourism and Generation Y, CAB International, Cambridge, 85-97.

[2] Lowrey, A. (2013) Do Millenials Stand a Chance in the Real World? New York Times, 1-11.

[3] Friedman, M. (1957) A Theory of the Consumption Function. Princeton University Press, Princeton University, Princeton.

[4] National Delinquency Survey (2007) Delinquencies Increase in Latest MBA National Delinquency Survey. Mortgage Bankers’ Association Press Release NDS. 
[5] Malley, J. and Moutos, T. (1996) Unemployment and Consumption. Oxford Economic Papers, 48, 584-600. http://dx.doi.org/10.1093/oxfordjournals.oep.a028586

[6] Mincer, J. (1960) Employment and Consumption. The Review of Economics and Statistics, 42, $20-26$. http://dx.doi.org/10.2307/1926091

[7] Romer, C.D. (1990) The Great Crash and the Onset of the Great Depression. Quarterly Journal of Economics, 105, 597-624. http://dx.doi.org/10.2307/2937892

[8] Park, M., Jang, H., Lee, S. and Brayley, R. (2010) Tourism and the N Generation in a Dynamically Changing Society: The Case of South Korea. In: Benckendorff, P., Moscardo, G. and Pendergast, D., Eds., Tourism and Generation Y, CAB International, Cambridge, 85-97.

[9] Greenberg, K. (2009) Ford Uses Social Media to Target Younger Buyers. Marketing Daily, 1-10.

[10] Jennings, G., Cater, C., Lee, Y.-S., Ollenburg, C., Ayling A. and Luny, B. (2010) Generation Y: Perspectives of Quality in Youth Travel Experiences in an Australian Backpacker Context. In: Benckendorff, P., Moscardo, G. and Pendergast, D., Eds., Tourism and Generation Y, CAB International, Cambridge, 58-72.

[11] Ngai, J. and Cho, E. (2012) The Young Luxury Consumers in China. Young Consumers, 13, 255-266. http://dx.doi.org/10.1108/17473611211261656

[12] Sheth, J.N., Newman, B.I. and Gross, B.L. (1991) Consumption Values and Market Choices: Theory and Applications. South Western, Cincinnati.

[13] Standard and Poor's (2011) Case Shiller Index. Standard and Poor’s, New York. http://us.spindices.com/indices/real-estate/sp.case-hiller-us

[14] Morgenson, G. (2007) Inside the Countrywide Lending Spree. New York Times. www.nytimes.com/2007/-8/26/business/yourmoney26country.html?pagewanted=all

[15] Goolsbee, A. (2007) Irresponsible Mortgages Have Opened Doors to Many of the Excluded. New York Times. www.nytimes.com/2007/03/29.../29scene.html

[16] Hahm, J. and Stiegerwald, D.G. (1999) Consumption Adjustment and Time-Varying Income Uncertainty. The Review of Economics and Statistics, 81, 32-40. http://dx.doi.org/10.1162/003465399767923791

[17] Weber, M., Guenther, R. and Wittich, C. (1978) Economy and Society: An Outlook of Interpretive Sociology. University of California Press, Berkeley.

[18] Ritchie, C. (2009) Young Adult Interaction with Wine in the UK. International Journal of Contemporary Hospitality Management, 23, 99-114. http://dx.doi.org/10.1108/09596111111101698

[19] Solnick, S.J. and Hemenway, D. (1998) Is More Always Better? A Survey on Positional Concerns. Journal of Economic Behavior and Organization, 37, 373-383. http://dx.doi.org/10.1016/S0167-2681(98)00089-4

[20] Alpizar, F., Carlsson, F. and Johansson-Stenman, O. (2005) How Much Do We Care about Absolute versus Relative Income and Consumption? Journal of Economic Behavior and Organization, 56, 405-421. http://dx.doi.org/10.1016/j.jebo.2002.10.007

[21] Harbaugh, W.T. (1998) A Signaling Explanation for Charity. American Economic Review, 88, 277-282.

[22] DeGroot, M. (1970) Optimal Statistical Decisions. Wiley, New York.

[23] Bell, D.J. and Valentine, G. (1997) Consuming Geographies: We Are Where We Eat. Routeledge, London.

[24] Jones, M. (2007) Feast: Why Humans Share Food. Oxford University Press, Oxford.

[25] Gunter, B., Hansen, A. and Touri, M. (2008) The Representation and Reception of Meaning in Alcohol Advertising and Young People’s Drinking. Department of Media and Communications, University of Leicester, Leicester.

[26] Coyne, S.M. and Ahmed, T. (2009). Fancy a Pint? Alcohol Use and Smoking in Soap Operas. Addiction Research and Theory, 17, 345-359. http://dx.doi.org/10.1080/16066350801902459

[27] Wong, N.Y. and Ahuvia, A.C. (1998) Personal Taste and Family Face: Luxury Consumption in Confucian and Western Societies. Psychology and Marketing, 15, 423-441. http://dx.doi.org/10.1002/(SICI)1520-6793(199808)15:5<423::AID-MAR2>3.0.CO;2-9

[28] Hung, K., Chen, A.H., Peng, N., Hackley, C. and Rungpaka, A.T. (2011) Antecedents of Luxury Brand Purchase Intention. Journal of Product \& Brand Management, 20, 457-467. http://dx.doi.org/10.1108/10610421111166603

[29] Kim, E.Y. and Kim, Y.K. (2005) The Effects of Ethnicity and Gender on Teens' Mall Shopping Motivations. Clothing and Textiles Research Journal, 23, 65-77. http://dx.doi.org/10.1177/0887302X0502300201

[30] Hirschmann, E.C. (1983) Predictors of Self-Projection, Fantasy Fulfillment, and Escapism. Journal of Social Psychology, 120, 63-76. http://dx.doi.org/10.1080/00224545.1983.9712011

[31] Nusair, K., Bilgihan, A., Okumus, F. and Cobanoglu, C. (2013) Generation Y Travelers' Commitment to Online Social 
Network Websites. Tourism Management, 35, 13-22. http://dx.doi.org/10.1016/j.tourman.2012.05.005

[32] Morton, L.P. (2002) Targeting Generation Y. Public Relations Quarterly, 47, 16-26.

[33] Chapin, S. (1928) A Quantitative Scale for Rating the Home and Social Environment of Middle Class Families in an Urban Community. Journal of Educational Psychology, 19, 99-111. http://dx.doi.org/10.1037/h0074500

[34] Chapin, F.S. (1932) Socioeconomic Status: Some Preliminary Results of Measurement. American Journal of Sociology, 37, 581-587. http://dx.doi.org/10.1086/215796

[35] McCormick, M.J. (1930) A Scale for Measuring Social Adequacy. Social Science Monographs, National Catholic School of Social Service, Washington DC.

[36] Sewell, W.H. (1943) A Short Form of the Farm Family Socioeconomic Status Scale. Rural Sociology, 8, 161-170.

[37] Cooper, C. (1974) The House Is a Symbol of the Self. In: Lang, J., Burnette, C., Moleski, W. and Vachon, D., Eds., Designing for Human Behavior, Dowden, Hutchinson and Ross, Stroudsburg, 130-146.

[38] Vershure, B., Magel, S. and Sadalla, E.K. (1977) House Form and Social Identity. In: Suedfeld, P., Russel, J., Wad, L.M., Szigeti, F. and Davis, G., Eds., The Behavioral Basis of Design, Book 2, Dowden, Hutchinson and Ross, Stroudsburg, 273-278.

[39] National Center for Policy Analysis (2013) Private School Choice: Options for Texas Children. Policy Report 345.

[40] Lin, T.C. (2005) The Determinants of Parental Choice of Education: The Case of Pennsylvania. Journal of Economics, 31, 45-59.

[41] Caroleo, F.E. and Pastore, F. (2012) Talking about the Pigou Paradox. International Journal of Manpower, 33, 27-50. http://dx.doi.org/10.1108/01437721211212510 
Scientific Research Publishing (SCIRP) is one of the largest Open Access journal publishers. It is currently publishing more than 200 open access, online, peer-reviewed journals covering a wide range of academic disciplines. SCIRP serves the worldwide academic communities and contributes to the progress and application of science with its publication.

Other selected journals from SCIRP are listed as below. Submit your manuscript to us via either submit@scirp.org or Online Submission Portal.
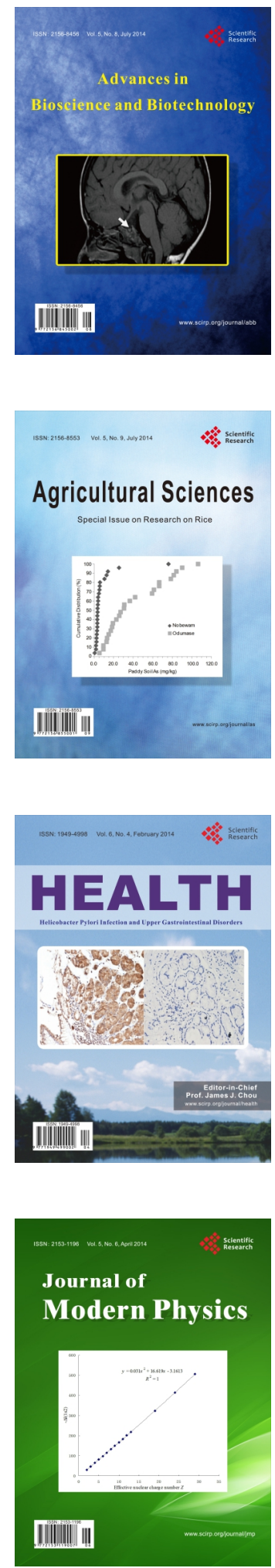
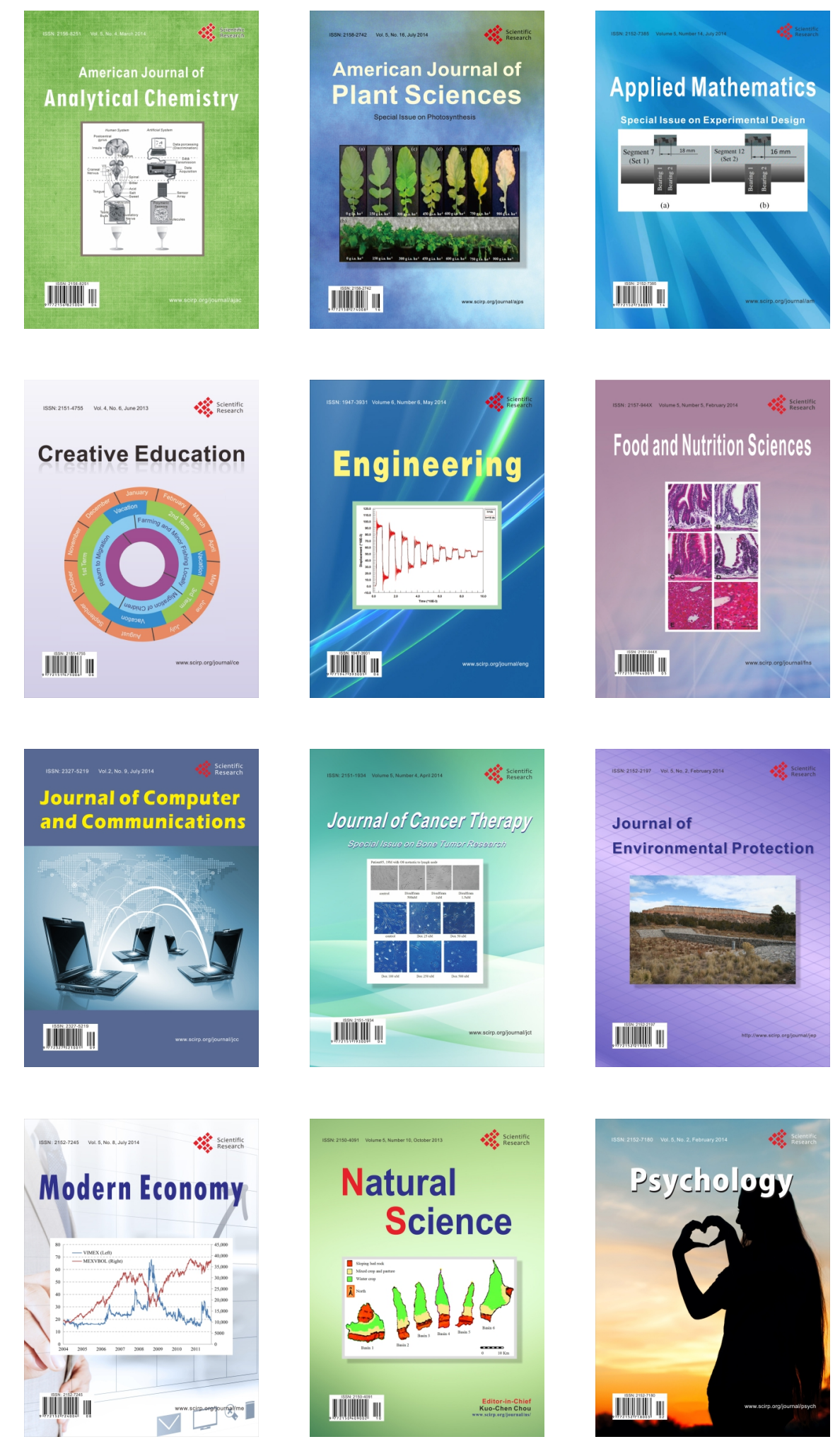